\title{
INVESTIGATION OF PHYSICAL-MECHANICAL PROPERTIES AND IMPACT ON SOIL OF GRANULATED MANURE COMPOST FERTILIZERS
}

\author{
Ramūnas MIELDAŽYS ${ }^{*}$, Eglè JOTAUTIENĖ ${ }^{2}$, Algirdas JASINSKAS ${ }^{3}$, \\ Juozas PEKARSKAS ${ }^{4}$, Raimonda ZINKEVIČIENÉ 5 \\ 1, 2, 3, 5 Institute of Agricultural Engineering and Safety, Faculty of Agricultural Engineering, \\ Vytautas Magnus University Agriculture Academy, Kaunas District, Lithuania \\ ${ }^{4}$ Agroecological Centre, Faculty of Forest Sciences and Ecology, \\ Vytautas Magnus University Agriculture Academy, Kaunas District, Lithuania
}

Received 26 June 2018; accepted 25 April 2019

\begin{abstract}
In recent years, the European countries recycle only 5-7\% of bio-waste. One activity of the biological waste disposal is granulation. The production of fertilizer from animal manure with supplement represents an important area of environmentally friendly bio-fertilizer production. This paper presents an investigation of estimation manure compost physical-mechanical properties for reuse of organic waste - cattle and cow manure, sugar production waste - molasses through new technology pellets production and of granulated fertilizer impact on soil. The experimental manure samples produced by industrial methods and samples produced in the laboratory from the time period of 2014 to 2017 were investigated. The following physical - mechanical characteristics were estimated: biometric indicators (dimensions, mass), volume and density of raw material and pellets, material and pellet's humidity and pellets strength. Experiments results have shown that the difference in limit strength between experimental and industrial organic compost pellets was about $5 \%$. Experiments of fertilizers on the impact on soil shown that the amount of nutrients added to the soil depends on the rate of the granulated compost fertilizer. As the norm increases, organic carbon, humus, mobile phosphorus and potassium increase in soil. Increases in soil fertility, improved agrochemical properties, soil organic matter accumulation and humus increase. Granulated compost fertilizers have no effect on soil acidity. The presented results could be helpful to the development of the fertilizing process by the granulated compost fertilizer for improvement of soil quality in small farms.
\end{abstract}

Keywords: manure compost fertilizer, organic waste management, raw material, granulation, physical-mechanical properties, molasses, soil fertility.

\section{Introduction}

Due to a significant decrease in the number of livestock in Lithuania, many farmers began to fertilize only with mineral fertilizers, this created a problem of soil degradation: lack of humus and nutrients, microbiological activity, deterioration of soil aggregates, and soil calcination began to acidify due to calcium and magnesium leaching (Baniūnienè \& Žèkaitè, 2005). The quality of the soil and environment is very important for the production of agriculture (Roeper, Khan, Koerner, \& Stegmann, 2005). The increasing problem of soil degradation requires a new revision for the use of organic fertilizers in agriculture. The solution of this problem is primarily due to the enrichment of soil with humus and the use of various organic compounds for fertilizing. In addition, beside the traditional organic fertilizers, new kinds, such as granular of manure and other organic fertilizers, are produced. The use of manure as an organic fertilizer greatly improves the soil structure, enriches both microorganisms and nutrients and stimulates the formation of humus.

According to The European Commission Decision of correcting the list of waste pursuant to Directive 2008/98/ EC (European Commission, 2014) manure is considered to be waste and treated off-site, code - 020106 . The manure should be utilized so that it is used by livestock owners as a fertilizer for crops, thereby reducing environmental pollution. But not treated and stabilized manure can be harmful for the environment etc. soil, ground water. Major environmental problems can be caused by failure to comply with the requirements of organic waste used as organic fertilizer. Surface water can be contaminated by scouring substances from manure into ditches, lakes,

*Corresponding author. E-mail: ramunas.mieldazys@vdu.lt 
rivers, etc. Pollutants such as nitrates, salts, pathogens can easily pollute not only surface but also groundwater. Intensive livestock farms can face a number of environmental problems, such as soil degradation or water pollution (Abelha et al., 2003; Bolan, Wong, \& Adriano, 2004).

Currently, only $5-7 \%$ of all bio-waste generated in European countries have been recycled. In case more biological waste was processed into more valuable products, it could replace up to $30 \%$ of mineral fertilizers based on phosphates. European countries import about 6 million tons of phosphate per year from other countries, however up to $30 \%$ of this amount could be converted from sewage sludge, biodegradable waste or manure produced fertilizers (European Commission, 2016). Based on the statistical data during the years 2010-2016 in Lithuania, agriculture, forestry and fishery industries produced about 3468 thousand tonnes of solid fraction manure and about 1496 thousand tons of slurry (Official Statistic Portal, 2017). Of this only a very small part of manure is composted. In the production of anaerobic biogas, only very small (about $3 \%)$ mixture of slurry and manure is currently treated (Brazas, 2012).

One of the many manure treatment ways is composting. Composting an active organic part in solid biological wastes makes it a stable product that can be used as a source of plant nutrition and as a conditioner for improving soil physical properties. The compost can improve soil structure, increase soil organic matter, inhibit soil pathogens and increase plant growth (Chen \& Inbar, 1993), while un-stabilized or immature compost application to agricultural soil may cause phytotoxicity and adversely affect the environment (Miikki, Senesi, \& Hanninen, 1997; Vandecasteele, Reubens, Willekens, \& De Neve, 2014). The European circular economic concept also appears in composting. The modification of the waste in agriculture with a quantitative reduction has become available with the realization of the economic competitive advantage based on the biodegradation of waste (Fogarassy, Czikkely, \& Tóth, 2018).

Recycling manure into valuable products is a more worthwhile than disposing it with the current methods (Lima \& Marshall, 2005). Recycling organic waste is a complex process, the final stage of which is granulation. Manure-based granulated fertilizers do not have pathogenic microflora, weed seeds, pathogenic ova or larvaes. Better physico-mechanical properties are acquired in the granular form: increased density of materials, volumetric density, mechanical durability, static strength, etc. Granulated products are easier to handle, transport and use in various technological processes such as spreading in soil. Such products have no expiration date, do not sow, are easier to spread in the soil and remain in the soil for longer time. One of the main advantages of granular organic fertilizers is the fact that much less fertilizer is required compared to traditional compost and biological humus. When the amount of nutrients in granular manure in the soil microflora is optimal, it quickly dissolves in water and is easily absorbed by plants. Thus, the main task for granulating materials is to improve the quality of the pellets (Pocius, Jotautiene, Pekarskas, \& Palsauskas, 2016; Jasinskas, Pekarskas, Kucinskas, \& Aboltins, 2016; Bhattacharya, Sett, \& Shrestha, 1989).

Organic granular fertilizers in agriculture are mostly used by organic farming and small farms, but granular organic fertilizers also could be used in traditional agriculture along with mineral fertilizers. In addition, it should be easy to spread granules by standard fertilizer spreading equipment. Granules can also be implanted into soil with sowing seeds (Pocius et al., 2016).

Manure granules can be successfully used not only in crop production, but also for growing vegetables and fruit. It is important to note that in order to improve plant nutrition in the initial stages of vegetation, complex fertilizers are added to organic fertilizer. However, the use of granulated manure for fertilizing plants is still under investigation. It is important to evaluate the effectiveness of various organic fertilizers produced from bird and cattle manure for agricultural crops and their effects to the soil agrochemical properties by comparing the efficiency with the impact of mineral fertilizers on plants and soil.

There still exist problems to produce good quality granulated fertilizers from biological wastes whose densification characteristics are unknown. Thus, methods how to make strong and durable granulated products are needed. As mentioned earlier, the physical-mechanical properties are very important for the quality of the pellets. Based on scientific research, breaking strength is the most commonly used method for measuring the hardness of fertilizer pellets. For fertilizers, this is a necessary trait for predicting fertilizer use and storage properties (Latifian, Liu, \& Mattiasson, 2012). For comparison to the other researcher's organic granules compressive strength tests shows that compost granules formed using municipal solid wastes was 44-113 N (Zafari \& Kianmehr, 2014). Granules made from composted pig solid fraction with biochar, whose compressive strength was 200-400 N (Pampuro, Bagagiolo, Priarone, \& Cavallo, 2017). Compressive strength of food waste compost granules the values were above $200 \mathrm{~N}$ (Chew et al., 2018). For higher granule strength and quality is it possible to use supplements like molasses, which are wastes too. According other authors the benefits of molasses addition can be reduced energy consumption, higher pellet strength, higher pellet density and bulk density, and lower moisture content (Mišljenović, Čolović, Vukmirović, Brlek, \& Bringas, 2016).

Investigations shows that on farm granulation of swine manure solid fraction composted with different organic waste materials can turn into organic fertilizer formulations. Investigation results enhance the importance of composting as a way to increase livestock farming sustainability and produce better manure compost for wider agricultural uses (Romano et al., 2014).

This paper is based on an investigation that aimed of determining physical properties of organic agricultural 
waste (cattle, cow manure compost, molasses) through new technology granules production and of granulated fertilizer impact on soil.

\section{Materials and methods}

There were investigated ten selected variants of cattle manure granules were produced by new method in industrial technology (from the time period of 2014 to 2017) and the laboratory conditions.

The five samples (6 $\mathrm{mm}$ diameters of granules without supplements) produced by industrial methods were: IP1 (production of 2014), IP2 (production of 2015), IP3 (production of 2016), IP4 (production of 2016 new technology of compost), IP5 (production of 2017). Since each year the production technology has improved, the characteristics of the granules belong to the company ownership. Granulated beef cattle compost fertilizers were made from the Angus and Angus-Simental cross-breed manure compost matured with special technology developed by ASU researchers. Cattle were fed only with haylings, giving some kind of lychees (lime salt). Concentrated feed and various protein additives were not used for feeding. Meat cattle manure was composted in a closed room (in a specially equipped building) to minimize the environmental impact of the composting process. The manure is stacked in racks and is turn over by the MENART 4800 SP (Belgium) turner. Compost stacks were turn over up to 10 times and observed the temperature in the compost stack. After rolling of the compost in the stack, the temperature rises to $65^{\circ} \mathrm{C}$, as temperature begins to fall, the compost stack starts rolling again. The compost is prepared as its temperature variations in the composting process are stable. Thereafter, the aging stage of compost, which lasts until 30 days, was followed. Prepared compost was milled and granulated by the pelletizer developed by ASU researchers.

For experimental granules productions in laboratory conditions there was used the same cattle manure compost (from 2015 production year) as it was used for industrial granules productions (named GA series) and farmer's cow manure compost (named KA series). The farmer's cow manure compost (KA series) samples were dried naturally up to $42 \%$ moisture for the raw material samples preparation. Subsequently, the samples were dried till $28 \%$ moisture in laboratory ventilation ducts for 48 hours and exposed to slowly heated airflow. Afterwards the prepared materials were placed in a hammer mill, where it was grinded to a flour-like fraction. Before the granulation, flour samples made by the laboratory conditions were moistened by spraying them with water emulsions. The first sample was moistened by spraying it with water containing no additives and the sample was named GA1. Other samples were moistened by spraying a water emulsion using molasses as an additive. The raw materials made of mixed water and molasses with ratio 1:1 was called GA2, and the emulsion with ratio 1:2 was called GA3. KA1 samples were obtained from straw and manure compost without any additives.
The KA2 samples were moistened by spraying the emulsion, which had a water-molasses ratio of 1:1.

In order to produce granules a small capacity granulator with horizontal matrix and $6 \mathrm{~mm}$ diameter channels were used. After granules cooled down their biometric parameters were evaluated, including their dimensions, moisture, volume and density.

The flour fractional composition and milling quality was determined using 8 different test sieve set RETSCH (Germany). Each test sieve body dimensions $200 \times 50 \mathrm{~mm}$ and it meet the requirements of ISO 3310-1. Diameters of test sieve holes respectively were $0 \mathrm{~mm}, 0.25 \mathrm{~mm}, 0.5 \mathrm{~mm}$, $0.63 \mathrm{~mm}, 1 \mathrm{~mm}, 2 \mathrm{~mm}, 3.15 \mathrm{~mm}, 4 \mathrm{~mm}$ and $5 \mathrm{~mm}$. By sieving a $100 \mathrm{~g}$ mass sample with a RETSCH AS 200 (Germany) sieve shaker, the following parameters were set: height $-1 \mathrm{~mm}$, sifting time $-1 \mathrm{~min}$, interval $-10 \mathrm{~s}$. After sifting, the remaining mass was weighed and the percentages of the sample particles were calculated. Each test for every sample was repeated 5 times.

The granules biometric parameters were determined and granules volume was calculated by measuring their length and diameter. It was used digital vernier caliper LIMIT $150 \mathrm{~mm}$ (PRC). It meets the requirements of DIN 863 (accuracy to $0.01 \mathrm{~mm}$ ). For experiments were randomly picked 10 granules to obtain the average value and error. The weight of the granules was evaluated by KERN ABJ (Germany) scales (accuracy to $0.001 \mathrm{~g}$ or $0.1 \mathrm{mg}$ ). After determination of pellet volume and weight there were calculated the density of all investigated granules samples (Pocius et al., 2016).

The moisture content of the flour and granular samples was determined by standard methods. The samples were weighed and dried at $105^{\circ} \mathrm{C}$ for 24 hours in a drying tube and the moisture content of each sample was calculated as a percentage. Calculations were performed according to standard methodology (Lithuanian Standards Board, 2007). By knowing the moisture content of the granules, the quantity of dry matter (DM) of each type of organic fertilizer granules was calculated.

The density of the samples was determined by using an empty $6 \mathrm{dm}^{3}$ cylinder. The cylinder was filled up with prepared flour or granule up to the upper edge, then the cylinder's weight was measured and using the results the density of the material was calculated. Bulk density was determined according to the standard methodology (Lithuanian Standards Board, 2002).

Granular strength tests were performed with the $5 \mathrm{kN}$ capacity Instron 5965 test machine (Illinois Tool Works Inc. (ITW), USA). Table model 5965 load frames meet the requirements of EN61236-1 (2006) Equipment for Measurement Control and Laboratory Use (Industrial Locations) using CISPR 11 (2004) per Class code A. Received parameters were saved to the Instron Bluehill ${ }^{\circ}$ test control software (version 3.11.1209). Static load velocities of $20 \mathrm{~mm} \cdot \mathrm{min}^{-1}$ and movement limit were also selected. Experiments with the samples of granules were carried out in a horizontal plane. Each test was performed for 5 times 
per granule type sample. The granules were selected for testing, with a ratio of height and diameter greater than $2: 1$. The experiment results were recorded every 0.1 seconds until the granule was disintegrated. Measurement error was $0.02 \%$. The statistical mathematical methods were used for processed the obtained data. The average values and their confidence intervals (CI) were calculated at a probability level of 0.95 .

Experiments on the impact of granular fertilizers on the soil were conducted in Aleksandras Stulginskis University Test Station. The soil was a medium loamy loam in a gleyy, a carbonated loam (Endocalcaric Amphigleyic Luvisol (Endoclayic, Drainic, Episiltic)). Investigations have been conducted for summer wheat plants. The size of the total field was $18 \mathrm{~m}^{2}(6 \times 3)$, the size of test field was $11 \mathrm{~m}^{2}(5 \times 2.2)$. Fields were selected for a random order. Samples of the soil were taken with a soil drill in $0-20 \mathrm{~cm}$ layer of the soil before the summer wheat fertilization and after harvest. The experiments were repeated three times. Granulated compost fertilizers were applied before sowing by cultivating them into the soil. Soil was fertilized with granular fertilizers with a diameter of $6 \mathrm{~mm}$.

Granular organic fertilizers tests on soils impact was made in spring of 2014 and 2015. Meteorological conditions in 2014 after summer wheat sowing were friendly for biodegradation of granular organic fertilizers in soil. In April an average precipitation was $21.3 \mathrm{~mm}$. The temperature of the day was more than $10{ }^{\circ} \mathrm{C}$. In May was $2.2{ }^{\circ} \mathrm{C}$ colder and there was $21.6 \mathrm{~mm}$ more precipitation than the perennial average. The summer wheat field was very wet. In June, it was $3.0^{\circ} \mathrm{C}$ colder and precipitation was $31.8 \mathrm{~mm}$ less than the perennial average. The average temperature in July was $20.6{ }^{\circ} \mathrm{C}$, it was even $4.0{ }^{\circ} \mathrm{C}$ higher than the perennial average. The precipitation was only $52.5 \mathrm{~mm}$ per month, which is $27.8 \mathrm{~mm}$ less than the perennial average. Spread out organic fertilizers has been slow to dissolve due to lack of moisture, and their total amount has not melt, which has affected their influence on spring wheat.

Summer wheat was sown on the test area on May 5 of 2015. By the beginning of sowing, only $9.9 \mathrm{~mm}$ of precipitation was within 17 days and moisture was absent in the arable soil layer. In May was $0.9^{\circ} \mathrm{C}$ colder and precipitation was $10.0 \mathrm{~mm}$ below the perennial averages. The lack of moisture has had a negative effect on the biodegradation of granular organic fertilizers in the soil and the release of nutrients from them. In July, precipitation was to $72.4 \mathrm{~mm}$ and the average monthly temperature was $17.4{ }^{\circ} \mathrm{C}$. It was $8.8 \mathrm{~mm}$ and $0.2{ }^{\circ} \mathrm{C}$ below to the values of perennials averages. Inserted organic fertilizer granules disintegrated and the nutrients were absorbed by the plants. In August was a little rainy, and it was only $4.0 \mathrm{~mm}$ of precipitation till to wheat harvest, average temperature was $20.6^{\circ} \mathrm{C}$. Dry weather was negative to the degradation of organic fertilizer granules and the nutritional relaxation from fertilizers.

Soil samples were analysed at Agrochemistry Research Centre laboratory of Lithuanian Centre for Agrarian and Forest Sciences. The $\mathrm{pH}$ of the soil was determined by potentiometric (Lithuanian Standards Board, 2005), organic carbon - dry combustion (International Organization for Standardization, 1995), humus - multiplication of organic carbon by the coefficient 1.724, mobile phosphorus $\left(\mathrm{P}_{2} 0_{5}\right)$ and potassium $\left(\mathrm{K}_{2} \mathrm{O}\right)$ - Egnerio-Rimo-Domingo A-L method (LVP D-07: 2015 6th edition).

\section{Results and discussion}

Fractional composition of raw material influences granulated fertilizers quality characteristic presented in Figure 1. The largest amount $(65.2 \pm 2.3 \%)$ of manure compost for industrial production (Figure 1a) mass accumulated

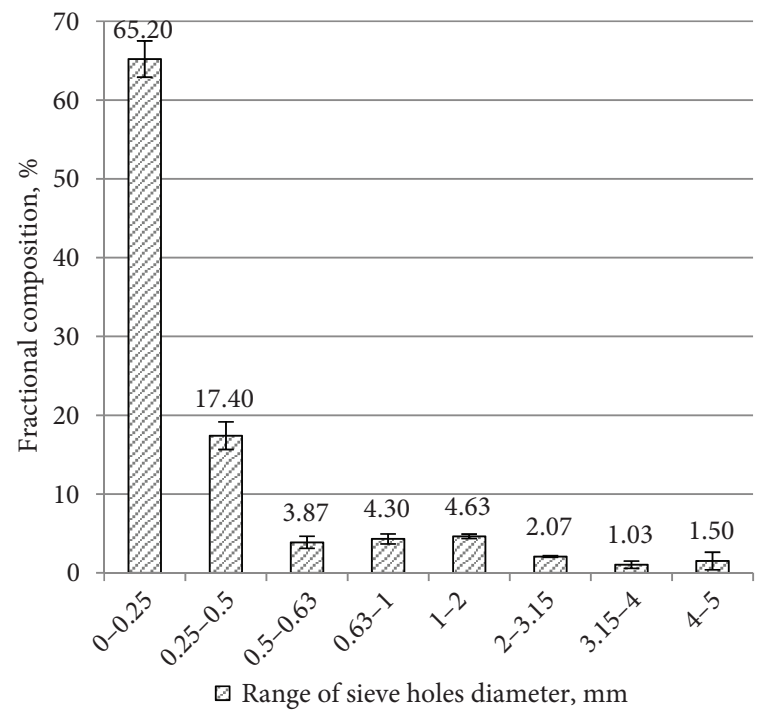

a)

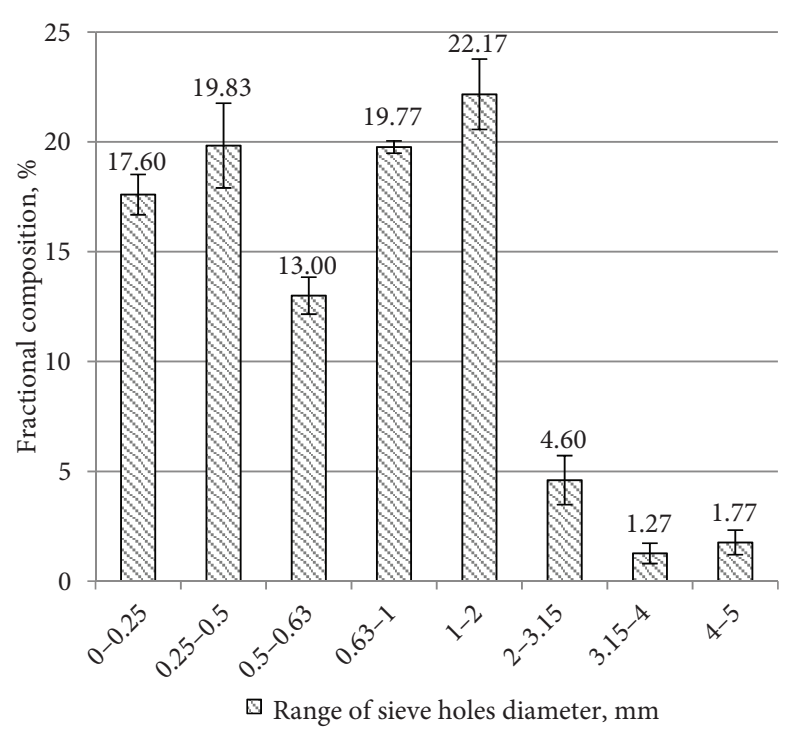

b)

Figure 1. Particle size of fractional composition of the raw material (mill) a) for granules IP and GA production and b) for granules KA production 
fraction range $0-0.25 \mathrm{~mm}$ in diameter on a sieve. When compost samples was sieving, a bigger quantity of dust was obtained. These results prove that milling the compost by using industrial milling devices results in a fine mill fraction. After evaluating the farmers cow compost mill (KA) fractional composition (Figure 1b), the maximum of mill fraction accumulated on the range 1-2 $\mathrm{mm}$ holes sieve $(22.17 \pm 1.6 \%)$.

A smaller quantity of flour fraction accumulated on the sieves range with $0.25-0.5 \mathrm{~mm}$ holes $(19.83 \pm 1.93 \%)$ and with $0.63-1 \mathrm{~mm}$ holes $(19.77 \pm 0.28 \%)$. Farmer's cow compost mill (KA) particles size distribution is bigger and industrial production mill particles were closer to the dust fraction.

It has been determined, that granules diameter of fertilizers produced by industrial methods (IP series) was in the range of $5.69 \pm 0.5 \mathrm{~mm}$. Binders were not used for granulating. This technology differs from other organic fertilizer production technologies because it helps to produce granular fertilizers of the same length and without binders. The average granules weight was about $0.33 \pm 0.15 \mathrm{~g}$ and average length of $9.7 \pm 0.12 \mathrm{~mm}$.

The farmers cow manure and straw compost granules produced in laboratory conditions (GA and KA series) had the granules diameter in the range of $5.55 \pm 0.9 \mathrm{~mm}$. The average experimental granules weight was about $0.48 \pm 0.15 \mathrm{~g}$ and the average length of $13.9 \pm 1.6 \mathrm{~mm}$. Granulating organic raw material with a traditional granulator with horizontal matrix produced a larger scattering granules length.

Humidity has a significant influence on interactions of plasticizer and enhances granule. Tolerable granule density

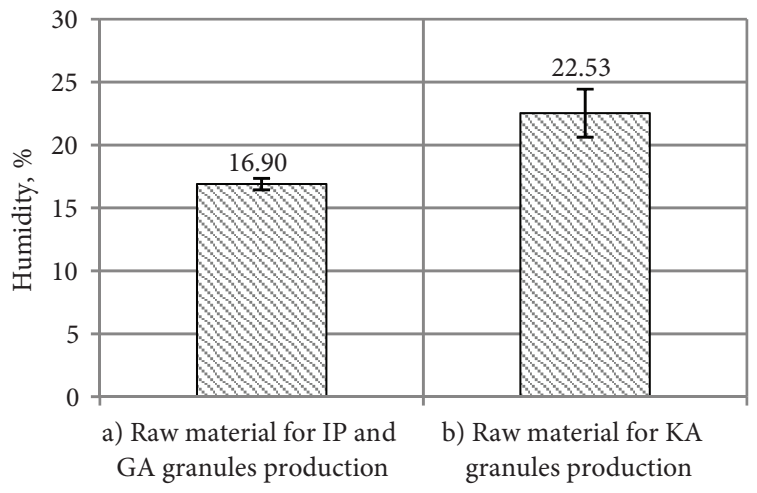

Figure 2. The comparison of raw material humidity for industrial and experimental granules a) Raw material for industrial pellets (IP) production and b) Raw material for experimental pellets (KA) production

is possible to achieve at lower moisture of raw material, but the compressive strength of pellet will be considerably lower. With increasing humidity, the capacity of pelletizing is reduced. The farmer's cow manure compost (KA) samples natural humidity was about $42 \%$, that's why it was dried till $28 \%$ humidity in a ventilation canal. After grinding the humidity of raw material was $16.90 \pm 0.46 \%$ for industrial production granules (IP series) and $22.53 \pm 1.91 \%$ for experimental granules production (KA series) (Figure 2). The granules humidity of industrial production (IP series) was from $12.09 \pm 1.18$ to $14.87 \pm 1.48 \%$ and experimental granules (GA and KA series) varied from $9.3 \pm 0.43$ to $10.40 \pm 0.23 \%$ (Table 1 ).

It was estimated that the mechanical properties of organic fertilizers depend on the amount of water used in

Table 1. The humidity, density and bulk density of organic fertilizer granules

\begin{tabular}{|c|c|c|c|c|}
\hline No. & Granules kind & Average humidity, \% & Density; (D.M.), $\mathrm{kg} \cdot \mathrm{m}^{-3}$ & Bulk density, $\mathrm{kg} \cdot \mathrm{m}^{-3}$ \\
\hline \multicolumn{5}{|c|}{ Industrial production } \\
\hline 1 & IP1 (production of 2014) & $12.09 \pm 1.18$ & 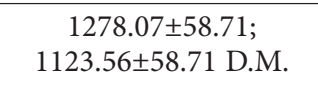 & $813.9 \pm 18.07$ \\
\hline 2 & IP2 (production of 2015) & $14.66 \pm 2.06$ & $\begin{array}{c}1217.46 \pm 64.37 \\
\text { 1038.98 } \pm 54.93 \text { D.M. }\end{array}$ & $749.3 \pm 19.92$ \\
\hline 3 & IP3 (production of 2016) & $14.84 \pm 0.30$ & $\begin{array}{c}1183.71 \pm 45.04 \\
1008.06 \pm 45.04 \text { D.M. }\end{array}$ & $729.4 \pm 26.69$ \\
\hline 4 & $\begin{array}{l}\text { IP4 (production of 2016, new } \\
\text { technology of compost) }\end{array}$ & $12.25 \pm 0.98$ & $\begin{array}{c}1116.81 \pm 54.33 \\
979.96 \pm 54.33 \text { D.M. }\end{array}$ & $751.2 \pm 45.51$ \\
\hline 5 & IP5 (production of 2017) & $14.87 \pm 1.48$ & $\begin{array}{c}1255.90 \pm 67.01 \\
\text { 1069.16 } \pm 67.01 \text { D.M. }\end{array}$ & $714.2 \pm 20.37$ \\
\hline \multicolumn{5}{|c|}{ Experimental production } \\
\hline 6 & GA1 (without additives) & $10.40 \pm 0.23$ & $\begin{array}{c}1315.30 \pm 125.9 \\
1178.51 \pm 125.9 \text { D.M. }\end{array}$ & $751.7 \pm 15.37$ \\
\hline 7 & $\begin{array}{l}\text { GA2 (with water to molasses } \\
\text { emulsion rate } 1: 1 \text { ) }\end{array}$ & $9.5 \pm 0.33$ & $\begin{array}{c}1434.65 \pm 40.55 \\
1298.36 \pm 40.55 \text { D.M. }\end{array}$ & $722.7 \pm 2.80$ \\
\hline 8 & $\begin{array}{l}\text { GA3 (with water to molasses } \\
\text { emulsion rate } 1: 2 \text { ) }\end{array}$ & $9.3 \pm 0.43$ & $\begin{array}{c}1450.03 \pm 30.02 \\
1315.18 \pm 30.02 \text { D.M. }\end{array}$ & $751.8 \pm 9.14$ \\
\hline 9 & $\begin{array}{l}\text { KA1 (with water to molasses } \\
\text { emulsion rate } 1: 1 \text { ) }\end{array}$ & $10.13 \pm 0.58$ & 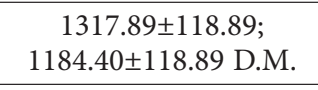 & $662.7 \pm 2.80$ \\
\hline 10 & $\begin{array}{l}\text { KA2 (with water to molasses } \\
\text { emulsion rate } 1: 2 \text { ) }\end{array}$ & $9.66 \pm 1.20$ & $\begin{array}{c}1374.81 \pm 44.78 \\
1242.01 \pm 44.78 \text { D.M. }\end{array}$ & $631.8 \pm 9.14$ \\
\hline
\end{tabular}


irrigation and the particle size of the raw material. Bulk density of raw material was $556.4 \pm 5.81$ for IP and GA series granules and $552 \pm 19.3$ for KA series granules production. The origin of organic raw materials had a negligible influence. From the data of Table 1, it can be seen that the average density of all IP series granules after granulation was $1210.39 \pm 73.07 \mathrm{~kg} \cdot \mathrm{m}^{-3}$. The average density of experimental granules (GA and KA series) after granulation was $1378.54 \pm 72.57 \mathrm{~kg} \cdot \mathrm{m}^{-3}$. Largest density is of GA and KA series experimental granules (from 1315.30 to $\left.1450.03 \mathrm{~kg} \cdot \mathrm{m}^{-3}\right)$.

The granular bulk density was bigger of the granules produced by industrial IP series (from 714.2 to $813.9 \mathrm{~kg} \cdot \mathrm{m}^{-3}$ ) then experimental KA series (from $631.8 \pm 9.14$ to $\left.662.7 \pm 2.80 \mathrm{~kg} \cdot \mathrm{m}^{-3}\right)$ methods. Density of experimental granules (from 1178.51 to $1315.18 \mathrm{~kg} . \mathrm{m}^{-3}$ ) of dried material (DM) was largest then produced in industrial method (from 979.96 to $1123.56 \mathrm{~kg} \mathrm{~m}^{-3}$ ) (Table 1).

The crushing strength test of industrial cattle manure compost (IP series) curves is shown in Figure 3 and experimental granules (GA and KA series) curves in Figure 4. In both granules series there were picked one average inherent curve from 5 samples on purpose to show the character of the force variation in granules crushing strength test. In the curves noticed granules breaking points, which are showing points where granule disintegrated mechanically. Maximum crushing load test results from 5 samples on each granules series and the average values and their confidence intervals (CI) showed in Figure 5.

Analysing the deformation curves it can be observed that the maximum crushing force achieved at $304.17 \mathrm{~N}$ and deformation was in range from $0.216 \mathrm{~mm}$ in IP1 granule case (Figure 3 ). Those granules series showed greatest resistance to mechanical load. The maximum crushing load test results with confidence intervals is shown in Figure 5 a). Maximum crushing loud force meanings were collected from Instron Bluehill test control software data. There was picked points from which force started to decrease for each sample. Average IP series granules crushing strength was $283.7 \pm 49.01 \mathrm{~N}$. Granules do not disintegrate immediately, because of their elasticity properties. The manure compost granules (IP1) with static stability of $357.1 \pm 105.9 \mathrm{~N}$ were found to be the most mechanically stable. The static stability of IP2, IP3, IP4 and IP5 ranged from around 245.2 to $272.6 \mathrm{~N}$. The smaller resistance to crushing load of granules was more suitable for dissolving fertilizers into soil.

The experimental granules test (GA and KA series)

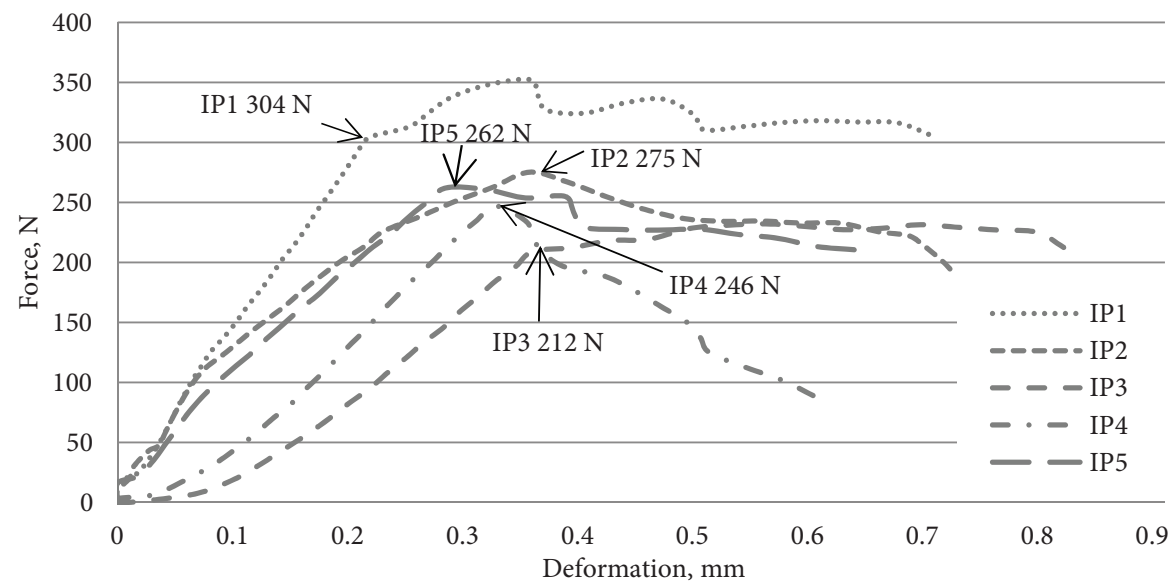

Figure 3. The strength test of industrial cattle manure compost granules IP1, IP2, IP3, IP4, IP5

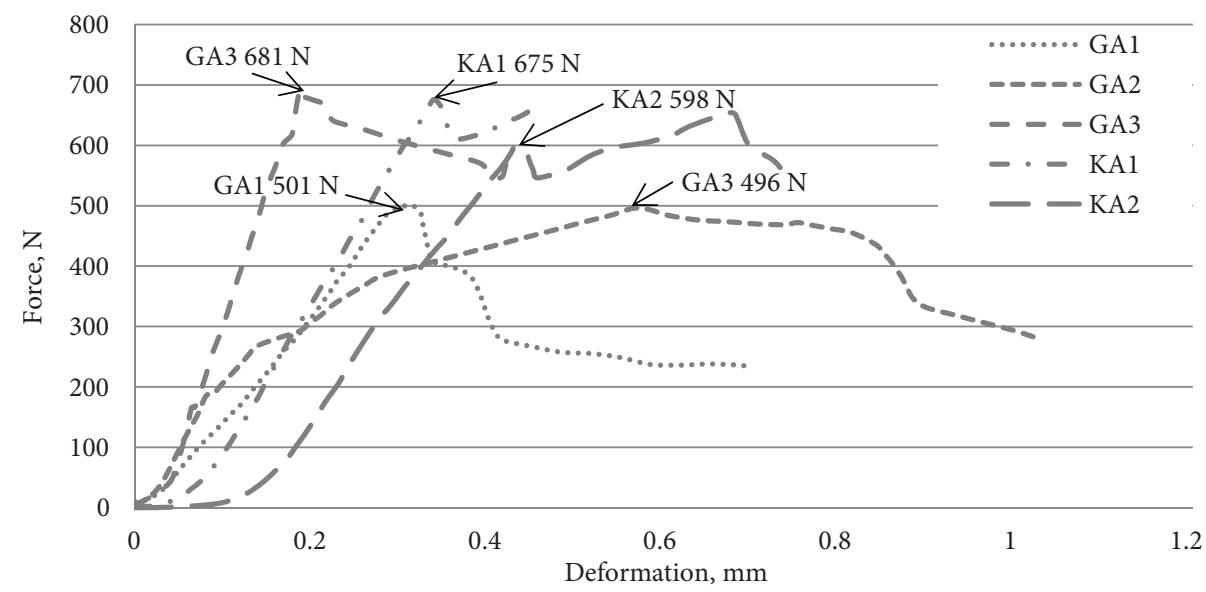

Figure 4. The strength test of experimental manure compost pellets GA1, GA2, GA3, KA1, KA2 


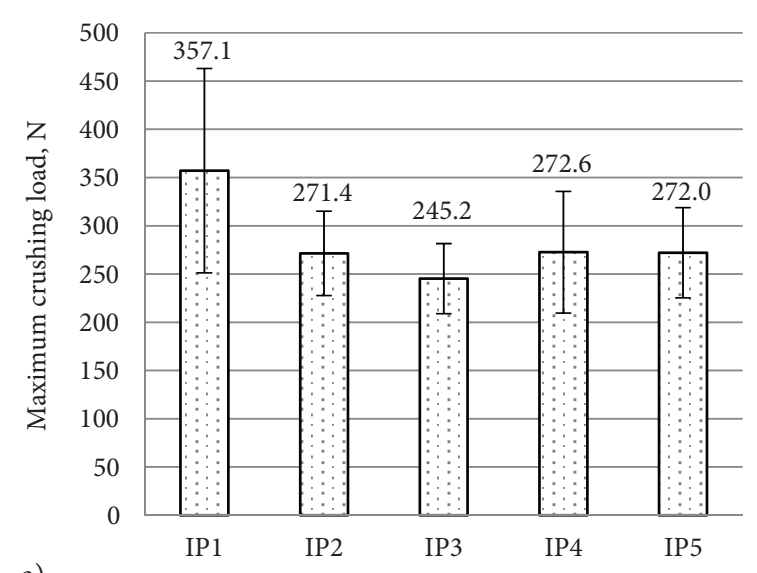

a)

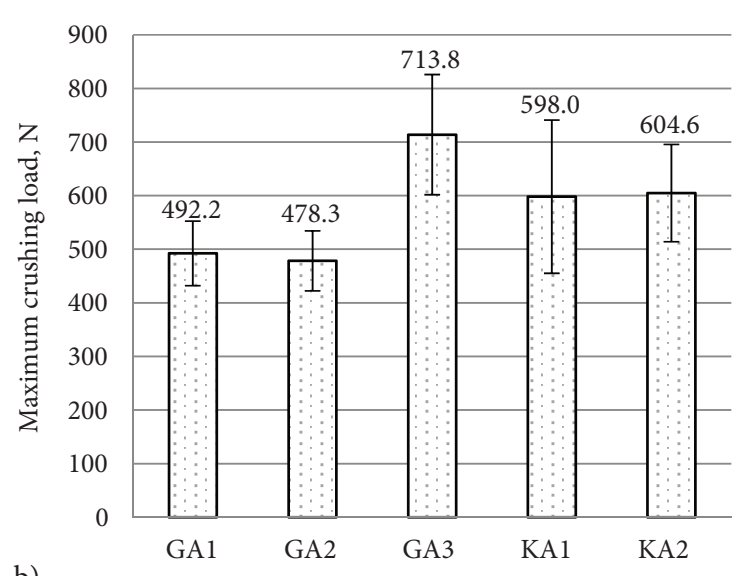

b)

Figure 5. Maximum crushing load test results for a) Industrial granules IP and b) Experimental granules GA and KA

results show that the maximum crushing force achieved more than $681.44 \mathrm{~N}$ and deformation was in range of $0.185 \mathrm{~mm}$ in GA3 granules case (Figure 4). Stronger granules show sharper fracture of deformation curve. Using the same crushing force on granules, the different deflection of the granules material is due to unequal raw material particle size and raw material density distribution in the granulation process. That's why deformation is quite different comparing KA to IP series granules.

The experimental granules test (GA and KA series) results show that the maximum crushing force achieved more than $681.4 \mathrm{~N}$ and deformation was in range from $0.18 \mathrm{~mm}$ in GA3 granules case. It was determined that biggest part of experimental granules under a force of around $500 \mathrm{~N}$ totally disintegrated (Figure 4). Increasing the concentration of molasses has shown stronger binding properties of the granules. The average strength of granules with molasses additives GA2 (rate 1:1) was $478.3 \pm 55.9 \mathrm{~N}$ (Figure $5 \mathrm{~b}$ ). The average strength of granules with molasses additives GA3 (rate 1:2) was about $713.8 \pm 112.1 \mathrm{~N}$. The average strength of KA1 granules without any supplement was more than $500 \mathrm{~N}$. The average strength of KA2 granules (sprinkling water with molasses emulsion rate 1:1) did not differ significantly (Figure $5 b)$. Average of all GA and KA series granules crushing strength was $577.4 \pm 110.2 \mathrm{~N}$. The strength of manure compost pellets with molasses additives increased from $6 \%$ to 9\%. A higher strength was obtained from experimental pellets (GA and KA series) than from granules produced by industrial methods (IP series). This may be attributed to the addition of supplement Molasses and raw material particle size.

All tested granules are sufficiently resistant to operating loads, are easy to transport, to store and it can be mechanically spread and inserted into the soil. It can be said that compost is highly humified and this is suitable as a raw material for the production of other bulk, granular and liquid organic fertilizers. The experiment results have shown that the limit strength of experimental and industrial organic compost granules varied from $5 \%$ to $10 \%$.

The chemical composition of cattle compost granular fertilizers is given in the table below (Table 2). According to other researches the low $\mathrm{C} / \mathrm{N}$ ratio signifies that the compost fertilizers is readily matured and can provide good mineralization in the form of accessible nitrogen for the plants to uptake and a high $\mathrm{C} / \mathrm{N}$ ratio will promote nitrogen immobilization, which means that the accessible nitrogen would be taken up by microorganisms preventing the plants from absorbing them (Al-Bataina, Young, \& Ranieri, 2016). In our case we got quite high $\mathrm{C} / \mathrm{N}$ ratio of cattle compost granulated fertilizers.

Table 2. Chemical composition of cattle compost granulated fertilizers production of 2014 (IP1)

\begin{tabular}{|l|c|}
\hline \multicolumn{1}{|c|}{ Indicator } & Granulated compost fertilizer \\
\hline Dry matter, \% & 87.2 \\
\hline Organic materials, \% & 72.0 \\
\hline $\mathrm{C} / \mathrm{N}$ & 17 \\
\hline $\mathrm{pH}$ & 8.5 \\
\hline $\mathrm{N}, \%$ & 2.76 \\
\hline $\mathrm{P}_{2} \mathrm{O}_{5}, \%$ & 1.34 \\
\hline $\mathrm{K}_{2} \mathrm{O}, \%$ & 5.44 \\
\hline $\mathrm{Mg}, \%$ & 0.58 \\
\hline $\mathrm{Ca}, \%$ & 2.07 \\
\hline $\mathrm{Fe}, \%$ & 0.16 \\
\hline $\mathrm{S}, \%$ & 0.39 \\
\hline
\end{tabular}

Tests of impact on soil were performed according to the following scheme: 1) not fertilized with organic fertilizers; 2) fertilized with $\mathrm{N}_{30}$ rate; 3) fertilized with $\mathrm{N}_{60}$ rate; 4) fertilized with $\mathrm{N}_{90}$ rate. The fertilizer rate for composted beef cattle compost is calculated on the basis of nitrogen content in organic fertilizers. The data is presented in the Table 3 .

The amount of nutrients entering into the soil depended on the rate of fertilizer applied. With the $\mathrm{N}_{30-90}$ granular compost fertilizer rate into the soil was inserted $1087.0-3261.0 \mathrm{~kg}$ of granular fertilizers with physical weight, $782.6-2347.8 \mathrm{~kg}$ of organic matter, $14.6-43.8 \mathrm{~kg}$ of $\mathrm{P}_{2} \mathrm{O}_{5}, 59.1-177.3 \mathrm{~kg} \mathrm{~K} 2 \mathrm{O}, 6.3-18.9 \mathrm{~kg} \mathrm{Mg}, 22.5-67.5 \mathrm{~kg}$ 
Table 3. The amount of nutrients entering in the soil by fertilizing with different cattle manure compost granulated fertilizers

\begin{tabular}{|c|c|c|c|}
\hline Indicator & $\mathrm{N}_{30}$ & $\mathrm{~N}_{60}$ & $\mathrm{~N}_{90}$ \\
\hline $\begin{array}{c}\text { Fertilize by physical } \\
\text { weight, kg }\end{array}$ & 1087.0 & 2174.0 & 3261.0 \\
\hline Organic materials, kg & 782.6 & 1565.2 & 2347.8 \\
\hline $\mathrm{N}, \mathrm{kg}$ & 30.0 & 60.0 & 90.0 \\
\hline $\mathrm{P}_{2} \mathrm{O}_{5}, \mathrm{~kg}$ & 14.6 & 29.2 & 43.8 \\
\hline $\mathrm{K}_{2} \mathrm{O}, \mathrm{kg}$ & 59.1 & 118.2 & 177.3 \\
\hline $\mathrm{Mg}, \mathrm{kg}$ & 6.3 & 12.6 & 18.9 \\
\hline $\mathrm{Ca}, \mathrm{kg}$ & 22.5 & 45.0 & 67.5 \\
\hline $\mathrm{Fe}, \mathrm{kg}$ & 1.7 & 3.4 & 5.1 \\
\hline $\mathrm{S}, \mathrm{kg}$ & 4.2 & 8.4 & 12.6 \\
\hline
\end{tabular}

Table 4. The influence of granulated cattle manure compost fertilizer (IP1) rates on soil biodegradation processes

\begin{tabular}{|c|c|c|c|c|c|}
\hline $\begin{array}{c}\text { Fertilizing } \\
\text { rates }\end{array}$ & $\mathrm{pH}$ & $\begin{array}{c}\mathrm{P}_{2} \mathrm{O}_{5}, \\
\mathrm{mg} \cdot \mathrm{kg}^{-1}\end{array}$ & $\begin{array}{c}\mathrm{K}_{2} \mathrm{O}, \\
\mathrm{mg} \cdot \mathrm{kg}^{-1}\end{array}$ & $\begin{array}{c}\text { Organic } \\
\text { carbon, } \%\end{array}$ & $\begin{array}{c}\text { Humus, } \\
\%\end{array}$ \\
\hline \multicolumn{6}{|c|}{ Results of year 2014} \\
\hline $\mathrm{N}_{0}$ & 7.6 & 201 & 111 & 0.79 & 1.36 \\
\hline $\mathrm{N}_{30}$ & 7.5 & 206 & 127 & 0.91 & 1.57 \\
\hline $\mathrm{N}_{60}$ & 7.5 & 216 & 136 & 1.00 & 1.72 \\
\hline $\mathrm{N}_{90}$ & 7.6 & 219 & 145 & 1.08 & 1.86 \\
\hline $\mathrm{R}_{05}$ & 0.17 & 7.42 & 6.24 & 0.06 & 0.05 \\
\hline \multicolumn{7}{|c|}{ Results of year 2015} \\
\hline $\mathrm{N}_{0}$ & 7.1 & 196 & 121 & 1.01 & 1.74 \\
\hline $\mathrm{N}_{30}$ & 7.1 & 202 & 130 & 1.11 & 1.91 \\
\hline $\mathrm{N}_{60}$ & 7.2 & 212 & 138 & 1.18 & 2.03 \\
\hline $\mathrm{N}_{90}$ & 7.1 & 218 & 144 & 1.22 & 2.10 \\
\hline $\mathrm{R}_{05}$ & 0.16 & 8.41 & 4.22 & 0.05 & 0.04 \\
\hline
\end{tabular}

Ca, $1.7-5.1 \mathrm{~kg}$ Fe and $4.2-12.6 \mathrm{~kg} \mathrm{~S}$ (Table 3).

Fertilization with organic fertilizers is limited by the Nitrates Directive and it is not possible to fertilize fertilizer norms higher than N 170. By fertilizing organic fertilizers without nitrogen, various amounts of other nutrients are added to the soil. Knowing the amount of nutrients that can be added can be adjusted to other mineral or trace element fertilizers and thus significantly save money (Table 4).

It was found that an application of granulated compost fertilizers restores degraded soil and improves the physical and chemical properties of the soil. Due to the high degree of humification of compost, the amount of humus in the soil could be restored gradually. If the amount of humus in the soil is less than $1.5 \%$, mobile phosphorus and potassium less than $100 \mathrm{mg} \mathrm{kg}^{-1}$, the amount of humus, phosphorus and potassium in the soil will increase within a few years after continuous fertilization with granular fertilizers (Table 4).

The efficiency of granular fertilizer depends on the rate of fertilization and the soil. It was found that granulated organic compost fertilizers have a long-term effect on soil. Granulated compost fertilizers do not affect soil $\mathrm{pH}$ values and do not affect the changes in its acidity. As the amount of phosphorous and potassium fertilizers added with granular compost increased (Table 3), the amount of mobile phosphorus and potassium in the soil increased. Mobile phosphorus was significantly (15.0-18.0 and $16.0-22.0 \mathrm{mg} \cdot \mathrm{kg}^{-1}$ ) increased in both research years, when fertilized with $\mathrm{N}_{60-90}$ fertilizer rate, as compared to non-fertilized soils. When fertilizing the $\mathrm{N}_{30}$ rate, only the trend of mobile phosphorus growth in soil was observed. With granular compost fertilizers potassium is significantly more than phosphorus added into the soil. It has a significant effect on the changes in mobile potassium in soil. In the course of fertilizing with all granular fertilizer rates $\mathrm{N}_{30-90}$, in both research years significantly $16.0-34.0$ and $9.0-23.0 \mathrm{mg} \cdot \mathrm{kg}^{-1}$ increased in mobile potassium soil compared to non-fertilized soil. Organic materials incorporated with granular compost fertilizers significant increased the amount of organic carbon and humus in the soil. The purpose of composting cattle manure was to maximize humification of compost so that the organic matter content is as strong as possible to the soil organic matter. According to the data of two years of research, all the rates of incorporated granular compost fertilizers essentially $(0.12-0.29$ and $0.10-0.21 \%)$ increased organic carbon $(0.21-0.50 \%)$ and humus content $(0.17-0.36 \%)$ in soil comparing to non-fertilized soils and comparing the rates of granular fertilizer with each other (Table 4). With increasing organic carbon and humus and mobile phosphorus and potassium content in soil, soil fertility increased, the values of agrochemical properties improved, soil organic material began to accumulate.

\section{Conclusions}

1. By analysing the granules produced by the industrial method it was found that the average IP series granules crushing strength was $283.7 \pm 49.01 \mathrm{~N}$. Industrial granules had diameter of $5.69 \pm 0.5 \mathrm{~mm}$ a range and an average length of $9.7 \pm 0.12 \mathrm{~mm}$. The average density of granules after granulation was $1210.39 \pm 73.07 \mathrm{~kg} \cdot \mathrm{m}^{-3}$.

2. Average crushing strength of experimental (GA and KA) series granules was 577.4 $\pm 110.2 \mathrm{~N}$. Produced granules had diameter of $5.55 \pm 0.9 \mathrm{~mm}$ a range and an average length of $13.9 \pm 1.6 \mathrm{~mm}$. The average density of experimental granules after granulation was $1378.54 \pm 72.57 \mathrm{~kg} \cdot \mathrm{m}^{-3}$. These granules were harder than those industrially produced. The maximum crushing force of experimental pellets was more than $500 \mathrm{~N}$. By increasing concentration of molasses, it is possible to achieve high strength pellets $(713.8 \pm 112.1 \mathrm{~N})$. This means that these pellets were easy to transport and to spread or to insert mechanically into the soil by fertilizing.

3. The amount of nutrients added to the soil depends on the rate of the granulated compost fertilizer. As the norm increases, organic carbon, humus, mobile phosphorus and potassium increase in soil. Increases in soil fertility, improved agrochemical properties, soil organic matter 
accumulation and humus increase. Granulated compost fertilizers have no effect on soil acidity.

4. When fertilizing granular compost fertilizers, 14.6-43.8 $\mathrm{kg} \mathrm{P}_{2} \mathrm{O}_{5}, 59.1-177.3 \mathrm{~kg} \mathrm{~K} \mathrm{O}$ were added, due to the fact that the $\mathrm{N}_{60-90}$ fertilizer increased significantly the amount of mobile phosphorus in the soil, and the amount of mobile potassium increased significantly when fertilized with $\mathrm{N}_{30-90} 782.6-2347.8 \mathrm{~kg}$ of organic matter is added with granulated compost fertilizers, which is responsible for the significant increase in soil organic carbon and humus content. It was found that the granulated organic compost fertilizers have a long-term effect on soil.

5. It can be concluded that the presented results could be useful to the development of the fertilizing process by the granulated compost fertilizer for improvement of soil quality in small farms.

\section{References}

Abelha, P., Gulyurtlu, I., Boavida, D., Seabra Barros, J., Cabrita, I., Leahy, J., Kelleher, B., \& Leahy, M. (2003). Combustion of poultry litter in a fluidised bed combustor. Fuel, 82, 687692. https://doi.org/10.1016/S0016-2361(02)00317-4

Al-Bataina, B. B., Young, T. M., \& Ranieri, E. (2016). Effects of compost age on the release of nutrients. International Soil and Water Conservation Research, 4(3), 230-236. https://doi.org/10.1016/j.iswcr.2016.07.003

Baniūnienè, A., \& Žèkaitè, V. (2005). Vasarinių kviečių vystymosi priklausomumas nuo sèjos laiko, sẻklos normos ir meteorologinių sąlygų [Dependence of summer wheat development on sowing time, seed rate and meteorological conditions]. Žemdirbystè. Mokslo darbai, 92(4), 80-92.

Bhattacharya, S. C., Sett, S., \& Shrestha, R. M. (1989). State of the art for biomass densification. Energy Sources, 11(3), 161-182. https://doi.org/10.1080/00908318908908952

Bolan, N. S., Wong, L., \& Adriano, D. C. (2004). Nutrient removal from farm effluents. Bioresource Technology, 94, 251-260. https://doi.org/10.1016/j.biortech.2004.01.012

Brazas, A. (2012). Reikalavimai kompostui ir kompostavimui [Requirements for compost and composting] (Project report). Lithuanian Ministry of the Environment.

Chen, Y., \& Inbar, Y. (1993). Chemical and spectroscopic analysis of organic matter transformations during composting in relation to compost maturity. In Science and engineering of composting: design, environmental, microbiological and utilization aspects (pp. 551-600). Washington, OH: Renaissance.

Chew, K. W., Chia, S. R., Yap, Y. J., Ling, T. C., Tao, Y., \& Show, P. L. (2018). Densification of food waste compost: effects of moisture content and dairy powder waste additives on pellet quality. Process Safety and Environmental Protection, 116, 780-786. https://doi.org/10.1016/j.psep.2018.03.016

European Commission. (2014). Commission Decision 2014/955/ EU of 18 December 2014 amending Decision 2000/532/EC on the list of waste pursuant to Directive 2008/98/EC of the European Parliament and of the Council Text with EEA relevance. Retrieved from https://publications.europa.eu/en/ publication-detail/-/publication/bb120f99-8ff5-11e4-b8a501aa75ed71a1/language-en

European Commission. (2016). Circular economy: new Regulation to boost the use of organic and waste-based fertilisers. Retrieved from http://europa.eu/rapid/press-release_IP-16827_en.htm
Fogarassy, C., Czikkely, M., \& Tóth, Z. (2018). Alternative utilization options in multi-function composting techniques. Hungarian Agricultural Engineering, 33, 11-16.

https://doi.org/10.17676/HAE.2018.33.11

International Organization for Standardization. (1995). Soil quality - Determination of organic and total carbon after dry combustion (elementary analysis) (ISO 10694). Retrieved from https://www.iso.org/standard/18782.html

Jasinskas, A., Pekarskas, J., Kucinskas, V., \& Aboltins, A. (2016). Investigation of natural magnesium mineral fertilizer granulation and determination of granule qualitative indicators. In Engineering for rural development: 15th international scientific conference proceedings (pp. 647-652). Jelgava, Latvia.

Latifian, M., Liu, J., \& Mattiasson, B. (2012). Struvite-based fertilizer and its physical and chemical properties. Environmental Technology, 33(24), 2691-2697. https://doi.org/10.1080/09593330.2012.676073

Lima, I. M., \& Marshall, W. E. (2005). Granular activated carbons from broiler manure: physical, chemical and adsorptive properties. Bioresource Technology, 96(6), 699-706. https://doi.org/10.1016/j.biortech.2004.06.021

Lithuanian Standards Board. (2002). Trąšos. Sutankintų trąšu piltinio tankio nustatymas (LST EN 1237) [Fertilizers - Determination of bulk density (tapped)]. Retrieved from http://www.lsd.lt

Lithuanian Standards Board. (2007). Dirvožemio gerinimo medžiagos ir auginimo terpès. Méginių paruošimas cheminiams ir fizikiniams tyrimams, sausuju medžiagu kiekio, drégnio ir laboratorijoje tankinto piltinio tankio nustatymas (LST EN 13040) [Soil improvers and growing media - Sample preparation for chemical and physical tests, determination of dry matter content, moisture content and laboratory compacted bulk density]. Retrieved from http://www.lsd.lt

Lithuanian Standards Board. (2005). Dirvožemio kokybè. pH nustatymas (LST ISO 10390) [Soil quality - Determination of $\mathrm{pH}$ ]. Retrieved from http://www.lsd.lt

Miikki, V., Senesi, N., \& Hanninen, K. (1997). Characterization of humic material formed by composting of domestic and industrial biowastes. Part 2. Spectroscopic evaluation of humic acid structures. Chemosphere, 34, 1639-1651. https://doi.org/10.1016/S0045-6535(97)00021-0

Mišljenović, N., Čolović, R., Vukmirović, Đ., Brlek, T., \& Bringas, C. S. (2016). The effects of sugar beet molasses on wheat straw pelleting and pellet quality. A comparative study of pelleting by using a single pellet press and a pilot-scale pellet press. Fuel Processing Technology, 144, 220-229. https://doi.org/10.1016/j.fuproc.2016.01.001

Official Statistic Portal. (2017). Retrieved from https://osp. stat.gov.lt/EN/statistiniu-rodikliu-analize?hash=af9953af3ff9-4d90-8c92-6335ddc0c012\#/

Pampuro, N., Bagagiolo, G., Priarone, P. C., \& Cavallo, E. (2017). Effects of pelletizing pressure and the addition of woody bulking agents on the physical and mechanicalproperties of pellets made from composted pig solid fraction. Powder Technology, 311, 112-119. https://doi.org/10.1016/j.powtec.2017.01.092

Pocius, A., Jotautiene, E., Pekarskas, J., \& Palsauskas, M. (2016). Investigation of physical-mechanical properties of experimental organic granular fertilizers. In Engineering for Rural Development: 15th International Scientific Conference Proceedings (pp. 1115-1120). Jelgava, Latvia.

Roeper, H., Khan, S., Koerner, I., \& Stegmann, R. (2005). Lowtech options for chicken manure treatment and application possibilities in agriculture. In Proceedings Sardinia, Tenth International Waste Management and Landfill Symposium (pp. 3-7). Environmental Sanitary Engineering Centre, Italy. 
Romano, E., Brambilla, M., Bisaglia, C., Pampuro, N., Pedretti, E. F., \& Cavallo, E. (2014). Pelletization of composted swine manure solid fraction with different organic co-formulates: effect of pellet physical properties on rotating spreader distribution patterns. International Journal of Recycling of Organic Waste in Agriculture, 3(4), 101-111.

https://doi.org/10.1007/s40093-014-0070-2

Vandecasteele, B., Reubens, B., Willekens, K., \& De Neve, S.
(2014). Composting for increasing the fertilizer value of chicken manure: effects of feedstock on $\mathrm{P}$ availability. Waste and Biomass Valorization, 5(3), 491-503.

https://doi.org/10.1007/s12649-013-9264-5

Zafari, A., \& Kianmehr, M. H. (2014). Factors affecting mechanical properties of biomass pellet from compost. Environmental Technology, 35(4), 478-486.

https://doi.org/10.1080/09593330.2013.833639 